\title{
Bio-Naphtha as Alternative for Olefins Feedstock in Indonesia
}

\author{
Candra Lutfi Widikrama and Indah Dwi Rachmawati
}

\begin{abstract}
Olefins consisting of ethylene, propylene, butadiene and butylene are one of the main raw materials for the petrochemical industry and intermediate materials for the production of various chemicals such as rubber and polymers. In Indonesia, the need for olefins that continues to increase is not accompanied by the availability of raw materials for manufacturing, namely naphtha which continues to decline. This causes a gap between supply and demand from olefins production. The alternative solution to this condition is to replace naphtha with raw materials that are more accessible in Indonesia. An alternative raw material that is abundant and can replace naphtha in Indonesia is palm oil which is then processed into bio-naphtha. Palm oil has the potential to replace naphtha because of its abundant availability in Indonesia and supported by applicable government regulations. The process used to make palm oil into bio-naphtha is the process of bio-synfining. In addition, the plastics produced from bio-naphtha is more environmentally friendly. This paper is intended to provide recommendations for the process of making bio-naphtha from crude palm oil in Indonesia.
\end{abstract}

Index Terms-CPO, bio-naphtha, olefins, petrochemical, Indonesia.

\section{INTRODUCTION}

Olefins consisting of ethylene, propylene, butadiene and butylene are one of the main raw materials for the petrochemical industry and intermediate materials for the production of various chemicals such as rubber and polymers $80 \%$ of the production of petrochemical plants is used to produce plastic [1], a material that is currently very essential and used everywhere. The need for olefins continues to increase, this is due to the increasing population, shifting lifestyles and urbanization. Prediction of increasing demand for olefins in Indonesia can be seen in Fig. 1. The highest demand for olefins is Butadiene [2], namely raw materials for making vehicle tires, synthetic rubber, gloves, and footwear.

Until now the process used to produce olefins is by steam cracking naphtha. The olefins production that has to be improved is facing challenges because the raw material (naphtha) for its production, continues to decline in availability. Naphtha itself is a mixture of hydrocarbon C5-C10 with a boiling point of $25-180^{\circ} \mathrm{C}$. At present Indonesia imports naphtha from another country. Tabel I shows the suppliers of naphtha. This data is retrived from PT. Chandra Asri, which is the biggest petrochemical industry in Indonesia.

Manuscript received February 13, 2019; revised May 7, 2019.

Candra Lutfi Widikrama and Indah Dwi Rachmawati are with Institut Teknologi Bandung, Indonesia (e-mail: lutfic1208@gmail.com, wira.indahdr@yahoo.com).
TABLE I: SUPPLIERS OF NAPHTHA IN 2016 [3]

\begin{tabular}{lll}
\hline \hline Supplier & US\$m & $\%$ \\
\hline Vitol Asia Pte & 304.2 & 35.6 \\
Marubeni Petroleum C Ltd & 237.5 & 27.8 \\
SCG Chemicals Co. Ltd & 81.8 & 9.6 \\
Chevron USA Inc & 78.4 & 9.2 \\
Shell International Eastern & 69.4 & 8.1 \\
Trading & 26.2 & 3.1 \\
Shell MDS (Malaysia) Sendirian & 22.0 & 2.6 \\
Konsorsium PT. Titis Sampurna & 3.2 & 0.4 \\
PT. Surya Mandala SaKTi & 0.1 \\
PT. Sadikun Chemical Indonesia & 0.5 & 3.7 \\
Others & 31.6 & 100 \\
Total & 854.9 & \\
\hline
\end{tabular}

In addition, the difference between olefins supply and demand in Indonesia is estimated at $28 \%$ in 2030. Graphs showing a gap between supply and demand in Indonesia are shown in Fig. 1. This large gap between supply and demand can be caused by the location of the Indonesian country causing Indonesia more difficult to access cheap raw materials compared to other countries such as Arabic country with their naphtha and North America with shale gas. Countries that have easy access to feedstock will easily produce olefins and lead global markets [4]. The alternative to this condition is to start looking for other raw materials to replace naphtha. Another process to produce olefins are from coal (coal to olefins) and from natural gas which convert to methanol and then converted to olefins (mthanol to olefins) But neither of those process is green technology and environmentally friendly. The solution is to use the bio-synfining process. This process can produce Bio-naphtha from various types of bio-feedstock. Table II shows the types of bio-feedstock which can be processed using Bio-Synfinning process.

TABLE II: TYPES OF BIO-FEEDSTOCK [10]

\begin{tabular}{ll}
\hline \hline No & Bio-feedstock \\
\hline 1 & Waste animal fat from food processing industry \\
2 & Waste fat from fish processing industry \\
3 & Vegetable oil residues (Stearin, PFAD) \\
4 & Technical corn oil \\
5 & Tall oil pitch \\
6 & Soybean oil \\
7 & Crude palm oil \\
8 & Camelina oil \\
9 & Jatropha oil \\
10 & Rapeseed oil \\
11 & Used cooking oil \\
\hline
\end{tabular}

Raw material replacement needs to take into account various factors because the substitute raw materials must be able to guarantee the sustainability of production. In addition, 
alternative raw materials must also consider environmental impacts so that the industry can be operated sustainable without damaging the environment. naphtha in Indonesia is palm oil. Palm oil in Indonesia can be processed into bio-naphtha and made a solution as a substitute raw material that can be used to produce olefins.

Alternative raw materials are abundant and can replace
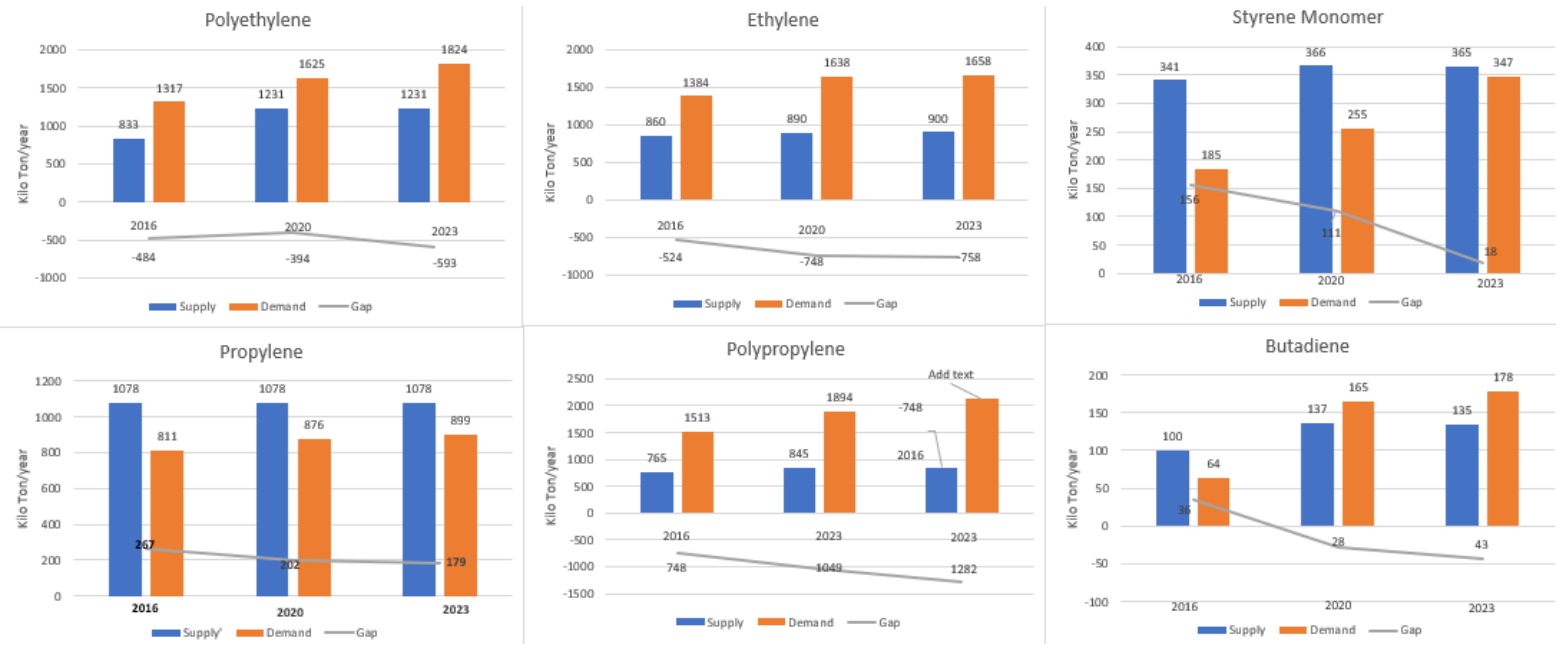

Fig. 1. Supply and demand for olefins in Indonesia [3].

\section{BIO-NAPHTHA's POTENTIAL}

Until now, olefins production is dominated by steam cracking naphtha which uses naphtha as a result of petroleum refining. Currently naphtha is chosen as the main ingredient of production because it produces the highest yield compared to other raw materials such as coal or natural gas [4]. However, because of Indonesia's depleted oil reserves, alternative raw materials are needed to replace naphtha.

Bio-naphtha is a mixture of C5 - C10 hydrocarbon compounds which are volatile and flammable with boiling points in the range of $30-200^{\circ} \mathrm{C}$ resulting from bio-based feedstock processing such as biomass and palm oil. Bio-naphtha is expected to be a substitute for naphtha from petroleum refining because it has similar physical and chemical properties. Table III shows the comparison of physical properties and impurities between naphtha from petroleum refining with bio-naphtha.

TABLE III: COMPARISON OF PHYSICAL PROPERTIES AND IMPURITIES BETWEEN NAPHTHA AND BIO-NAPHTHA [5], [6]

\begin{tabular}{lll}
\hline \hline Parameters & Naphtha & Bio-Naphtha \\
\hline Boilin point $\left({ }^{\circ} \mathrm{C}\right)$ & $25-180$ & $30-200$ \\
Density $\left(\mathrm{kg} / \mathrm{m}^{3}\right)$ & 700 & 670 \\
Total Sulphur $(\mathrm{ppm}$ Max) & 650 & 0 \\
Color & Colorless & Colorless \\
Olefins $(\% \mathrm{wt})$ & Max 1 & $<0.5$ \\
Aromatics $(\% \mathrm{wt})$ & 5 & $<1$ \\
\hline
\end{tabular}

The nature of bio-naphtha with naphtha from the table seen is similiar, meaning that it can be directly used to make olefins so that it will not require large costs for the migration from naphtha to bio-naphtha. Moreover, Neste Oil, Finnish oil refining and marketing company, reported that bioplastic products produced from renewable naphtha (Bio-Naphtha) can be recycled with conventional fossil-based plastic products, and can be used as a fuel in energy generation following recycling. This finding proves that bio-naphtha can be a substitute for conventional naphtha [7].

\section{A. Availability of Palm Oil as Raw Material}

Indonesia is the largest palm oil producer in the world with an oil palm plantation area reaching 11.9 million hectares in 2017 and is expected to reach 13 million hectares by 2020 [1]. This has caused Indonesia to become the largest palm oil exporter in the world. The majority of palm oil production is exported to China, India, Pakistan and the Netherlands. Table III shows the total production and total CPO exports throughout 2008 - 2016.

TABLE IV: TOTAL PRODUCTION AND TOTAL CPO EXPORTS THOUGHOUT

\begin{tabular}{lll}
\multicolumn{3}{c}{$2008-2016[1],[8]$} \\
\hline \hline Year & Production (million tons) & Export (million tons) \\
\hline 2008 & 19,2 & 15,1 \\
2009 & 19,4 & 17,1 \\
2010 & 12,8 & 17,1 \\
2011 & 23,5 & 17,6 \\
2012 & 26,5 & 18,2 \\
2013 & 30 & 22,4 \\
2014 & 31,5 & 21,7 \\
2015 & 32,5 & 26,4 \\
2016 & 31,5 & 26,6 \\
\hline
\end{tabular}

From Table II above it can be concluded that the availability of palm oil to be processed into derivatives which have higher values is very high. However, this potential has not been optimally developed due to various constraints to its application, such as high investment costs, relatively low technological efficiency, geographical location, and social factors of the community as energy users. All these obstacles cause crude palm oil or CPO (crude palm oil) to be largely an export commodity.

\section{B. The Process of Making Bio-naphtha}

At present most olefins are produced through the process of naphtha steam cracking, can also be produced from natural gas or biogas via methanol and the oxidative coupling route. Coal can be used with the gasification or liquefaction process while biomass can be used by gasification, fermentation, and pyrolysis. According to [4], for the period 2030-2050, the 
synthesis of olefins from coal is preferred when viewed from the production costs of olefins production. However, the continuous use of coal will have a negative impact on the environment. Therefore, materials that have properties similar to naphtha are needed, but are more environmentally friendly.

The Bio-Synfining process can meet those needs. This process, catalytically converts fatty acids and / or glycerides into waste greases, vegetable oils, and algae into paraffinic hydrocarbon fractions without residual oxygenates. In, short this process can convert long-chain hydrocarbons into hydrocarbons with shorter chains with the help of a catalyst.

Palm oil or better known as Crude Palm Oil (CPO) is an oil that is dominated by palmitate and oleat, oil with a structure in the form of carbon chains totaling 16 to $18 . \mathrm{CPO}$ is put into a CPO storage tank, then pumped into the heating unit to reach the temperature in the degumming process. Degumming is a process of removing impurity in the form of phosphatide, wax, and other impurities usually by adding phosphoric acid. This process also aims to minimize the amount of oil wasted (oil losses). Actually, cleaning can also be done using the enzymatic degumming method. However, degumming products in the form of gum from enzymatic degumming cannot be sold as lecithin. While the results of degumming using phosphoric acid can be resold as lecithin which can be used as an emulsifier, animal feed, and additives in the chemical industry.

After going through a degumming process, clean $\mathrm{CPO}$ from impurities is then transferred to the preheater to be heated to a temperature of around $340 \mathrm{oC}$ and then fed to a hydrocracker reactor operating in a temperature range of 148 - $480 \mathrm{oC}$, to be reacted with hydrogen at a pressure of 1000-2000 psig contains nickel-molybdenum (NiMo) catalyst with LHSV flow rate $0.2 \mathrm{~h}-1$ to $10 \mathrm{~h}-1$ [9]. Preferably to maintain the active metal sulfide functionality of the catalyst despite the absence of sulfur organic in CPO, before entering a hydrocracker, CPO is mixed with sulfide compounds such as dimethyl disulfide and carbon disulfide [4].

The reactions that occur can be summarized with the following oleic acid model

$$
\begin{aligned}
& \mathrm{C}_{17} \mathrm{H}_{33} \mathrm{COOH}+4 \mathrm{H}_{2} \rightarrow \mathrm{n}-\mathrm{C}_{18} \mathrm{H}_{38}+2 \mathrm{H}_{2} \mathrm{O} \\
& \mathrm{n}-\mathrm{C}_{18} \mathrm{H}_{38}+\mathrm{H}_{2} \rightarrow \mathrm{n}-\mathrm{C}_{8} \mathrm{H}_{18}+\mathrm{i}-\mathrm{C}_{10} \mathrm{H}_{22}
\end{aligned}
$$

The first reaction is called the hydrodeoxygenation (HDO) reaction, which is the main reaction in the hydrotreating process. First, the hydrogenated and deoxygenated fatty acid chains become straight chain paraffins. When fatty acids bind to glycerol, propane will be produced as n-paraffin increases. Second, paraffin formed will experience hydrocracking to be shorter paraffin with the distribution of products between $\mathrm{C}_{3}-\mathrm{C}_{18}$ and $\mathrm{C}_{4}-\mathrm{C}_{10}$ taken as bio-naphtha. The bio-naphtha product produced has a boiling point range of $21-204{ }^{\circ} \mathrm{C}$ with an olefins fraction of less than $0.6 \%-\mathrm{w}$, the fraction of naphthenes is less than $6.5 \%-\mathrm{w}$, and the aromatic fraction is less than $1 \%$-w. Bio-synfining process is showed in Fig. 2.

\section{Commercial Production of Bio-naphtha}

Until now there is still no industry that is specialized in producing bio-naphtha with $\mathrm{CPO}$ raw materials. The company that can produce bio-naphtha is Neste oil, an oil refining and marketing company located in Espoo, Finland. Bio-naphtha produced in Neste is obtained from the byproduct of making bio-diesel.

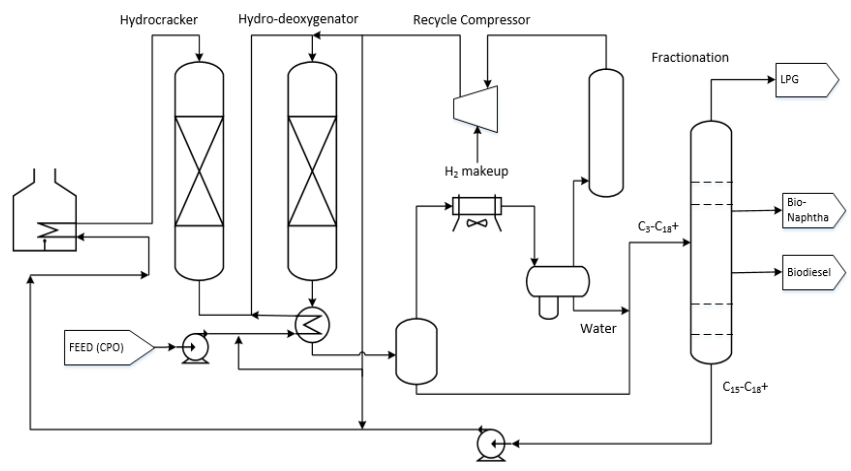

Fig. 2. Bio-synfining process for making bio-naphtha [2].

The lack of development of bio-naphtha production from $\mathrm{CPO}$ is because CPO is more widely used as an alternative fuel for diesel.And in Indonesia itself there are some problems because the extend of palm oil plantations established and poor land management. The main one is overlappting licences especially for conservation forest and protected forest. Another one is from taxes, although the palm oil export is increasing, it does not inrease state revenues from taxes, in fact in 2014 tax revenue fell as oil palm production and exports increased [10]. It is clear that there are companies that do not pay taxes. This indicates a lack of government oversight of company activities so that the company does not feel bound by the applicable law.

\section{Analysis of Related Government Regulations}

The use of palm oil as a raw material for making bio-naphtha which will later become olefins is strongly supported by the Indonesian government. In 2019, the government is targeting the presidential regulation on the development of an Indonesian Sustainable Palm Oil (ISPO) system [11]. The regulation contains the National Sustainable Palm Oil Action Plan (RAN-KSB) which serves as a guideline for all stakeholders in the palm oil sector to focus on the development of a sustainable palm oil industry. Capacity development includes the use of certified seeds and increased training in Good Agricultural Practices (GAP).

Data from the Ministry of National Development Planning / Bappenas shows that the achievement of ISPO certification has only reached $19.5 \%$ of the target set by the government at $70 \%$ in 2020 [11].

The government will form the Indonesian Sustainable Palm Oil Forum (FoKSBI) at the national level as well as in the 18 oil palm producing provinces to act as executors of the RAN-KSB [11]. Palm oil production has been hampered by accusations of crude oil palm from Indonesia not being environmentally friendly. The issue of deforestation that emerged in 2017 has become very sensitive in the palm oil industry. Regardless of the motives, the reason was finally behind France to have a progressive tax for Indonesian CPO products [12].

ISPO is one way to prove that this accusation is not true. The government continues to drive palm oil production and 
processing in Indonesia. The president of Indonesia said, as long as the selection of seeds is correct and done well, then the production of oil palm with existing plantation land is estimated to be more than double [12]. At present Indonesia has become the world's largest CPO producer, a level above Malaysia [12]. So, if improvements to the production system with superior seeds and optimal maintenance are carried out, $\mathrm{CPO}$ production is estimated to continue to be improved.

\section{CONCLUSION}

With abundant oil availability, and the government supporting it, CPO has the potential to be processed into bio-naphtha. With the use of bio-naphtha, Indonesia is able to utilize palm oil so that Indonesia can meet the needs of olefins and produce its own environmentally friendly and sustainable.

\section{REFERENCES}

[1] Indonesian Palm Oil Statistis, Jakarta. BPS-Statistics Indonesia, 2017.

[2] C. Eren, "Petrochemicals 2030: Reinventing the way to win in a changing industry," Mckinsey, February 2018.

[3] Management Presentation, PT Chandra Asri Petrochemical TBK. Jakarta, 2017.

[4] A. Ramin, H. L. Tomlinson, and G. Roth, "Biorenewable naphtha composition and methods of making same," U.S. Patent No. 8,581,013. 12 Nov. 2013.

[5] Material Safety Data Sheet Neste Naptha, Suncor Energie, 2019. Indonesian Palm Oil Statistis, Jakarta. BPS-Statistics Indonesia, 2017.

[6] Material Safety Data Sheet Neste Renewable Naptha. (2016). Neste oil essential palm oil statistics. [Online]. Available: http://www.palmoilanalytics.com/files/epos-final-59.pdf

[7] Neste Oil Corporation. (May 2012). Neste Oil adds NExBTL renewable naphtha suitable for producing bioplastics to its corporate customer product range. [Online]. Available: https://www.neste.com/neste-oil-adds-nexbtl-renewable-naphtha-suita ble-producing-bioplastics-its-corporate-customer
[8] Essential Palm Oil Statistics. (2017). [Online]. Available: http://www.palmoilanalytics.com/files/epos-final-59.pdf

[9] S. P. Pyl et al., "Biomass to olefins: Cracking of renewable naphtha," Chemical Engineering Journal, vol. 176, pp. 178-187, 2011. Material Safety Data Sheet Neste Naptha, Suncor Energie, 2019.

[10] Kajian Sistem Tata Kelola Komoditas Kelapa Sawit. 2016. Direktorat Penelitian dan Pengembangan Kedeputian Pencegahan, Komisi Pembereantasan Korupsi. Jakarta.

[11] S. Pablo. (November 2018). Aturan Sait Berkelanjutan Rilis 2019, Sertifikat ISPO Wajib! [Online]. Available: https://www.cnbcindonesia.com/news/20181129164023-4-44305/atur an-sawit-berkelanjutan-rilis-2019-sertifikat-ispo-wajib

[12] H. Zulkifli. (May 2018). Tata kelola sawit nasional. [Online]. Available:https://ekonomi.kompas.com/read/2018/05/23/204200526/t ata-kelola-sawit-nasional

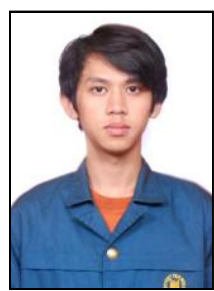

Candra Lutfi Widikrama was born in Sukabumi, West Java on May 5th, 1996. He is a final year chemical engineering student at Institut Teknologi Bandung, Indonesia. He has focused on catalyst and reaction engineering since 2018 and is currently researching matrix for residual fluid catalytic cracking reactions (RFCC).

The first of three siblings is a alumnus of SMAN 1 Cibadak, Sukabumi. He is a scholarship recipient of PT. Chandra Asri and has internship experience at PT. Semen Indonesia. Besides being active in student affairs, he was also a chemistry laboratory assistant.

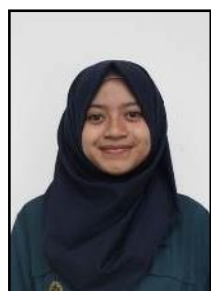

Indah Dwi Rachmawati was born in Bandung, West Java on July $9^{\text {th }}, 1997$. She is a final year chemica engineering student at Institut Teknologi Bandung, Indonesia. She has focused on process safety and electrochemistry energetics since 2018 and is currently researching corrosion engineering.

The second of three siblings is a alumnus of SMAN 8 Bandung. He is a scholarship recipient of Sinerg Foundation (Beasiswa Pemimpin Bangsa V) and PT. Chandra Asri. She has internship experience at PT. Petrokimia Gesik. Besides being active in student affairs, he was also a chemistry laboratory assistant. Her publication has entitled "Korosi Baja Karbon di Dalam Larutan $\mathrm{NaCl}$ Mengandung $\mathrm{H}_{2} \mathrm{~S}$ " has been presented in Seminar Nasional Material 2018. She want to express her gratitute for Sinergi Foundation which has sponsored this paper. 